\title{
Privacy and the peer-review system
}

\author{
There are disturbing signs that the peer-review system for unpublished manuscripts is no longer as \\ secure as it should be. Commercial competition is not the most serious a cause of trouble.
}

MosT complaints about the peer-review system say that it is unjust. But what about the possibility that it has become unworkable? A week ago, a patent attorney wrote on behalf of an author, whose manuscript could not be published in Nature, asking whether referees are required to sign a "confidentiality agreement" in advance of being asked to look at authors' manuscripts. His letter went on to allege that the existence of his client's manuscript, and perhaps even its content, had been disclosed to a graduate student at a university in the United States by a member of the faculty, who claimed to have been one of the referees (which is true).

Coincidentally, a colleague of another author (whose manuscript has also been refused) telephoned to say that one of the audience at a recent meeting had chipped in, at the end of a brief formal presentation of the still unpublished work, with a detailed critique based on a sight of the unpublished manuscript, said to be "all over the scientific community". That claim is probably exaggerated; probably the questioner meant "all over my laboratory" (where one of the referees also works). But whatever the truth, the tale is evidence that the peer-review system, whatever its other weaknesses, is not always the confidential means by which colleagues are consulted about the merits of each other's work.

To many people, the cynical and the embittered for obvious reasons, this discovery wll not be a surprise. Why, they will say, should scientists who are good enough to help journals (usually without material reward) to decide what to publish also keep their own counsel about the manuscripts that pour endlessly across their desks? And now, when so much of academic science has an obvious commercial value, is it not inevitable that somebody who is actively working in a particular field will make the most of a scientific manuscript sent for review?

There is no denying that access to an unpublished manuscript can often be of great value to a referee. There is a host of fields in which this is the case - the development of semiconductor devices, solidphase catalysts and photovoltaic devices driven by solar energy, for example. But the competition is especially fierce in the applications of molecular biology to biotechnology where the knowledge of even a short nucleotide sequence of a gene may, for example, enable a competitor to construct the nucleotide probe with whose help the intact gene may be fished out of a DNA library. That, legend has it, is why people speaking on these topics at meetings in advance of publication tend to show their slides of nucleotide sequences for only very brief intervals - and why there has emerged a group of auditors skilled at memorizing a whole string of nucleotides seen only for a few seconds.

So the incentives for referees to break confidence are considerable. Authors are often painfully aware of the dangers, sometimes to the point of seeming paranoid on the subject. An author's recent claim that a recent piece of published work (which turned out to be mistaken) was being replicated at two other laboratories within a week or so of the submission of the original article was found, on investigation, to be only half-true; the work had been begun before, and was independent. The author had, however, guessed the geographical location of two of the three referees.

These are not the only hazards of the peer-review process, as exemplified by a sad tale from earlier this year. A manuscript reporting part of an incomplete amino acid sequence was in part concerned with what seemed an interesting homology with another amino acid sequence, sent for review to one whose interests include the maintenance of a databank. In the event, the referee spotted a more complete and striking homology than the author had claimed. That information was conveyed to the author together with a tactless suggestion (which was misunderstood) that there should be some formal recognition of what the referee had done. The upshot was that the article was withdrawn (fortunately to be published elsewhere) and the offended author convinced, as he explained, that he "had been robbed of the joy of discovery".

So should referees also take care not to let their intellectual curiosity run riot over papers sent to them for review? Of course not. All journals know of papers that have been enormously improved by the contributions made by referees. Sometimes, authors are ready to acknowledge this, although it must be rare that a referee's contribution is so great that the interpretation of data is entirely transformed. But these, in any case, are not the occasions when authors most fear that their data will be misused before publication.

The problems recently encountered with manuscripts whose content may have immediate practical value in, for example, biotechnology are much more taxing. The obvious danger is that improper commercial use will be made of data that are still confidential, which is why journals try to use their common sense and not send papers for review to people likely to have a commercial interest in them. But there are two circumstances that make this ideal in general unattainable. First, and quite deliberately, the larger biotechnology companies have made a point of keeping close links with academic science, partly because the step between discovery and practical innovation is so short and partly because it helps in the recruitment of able people. Second, and much more serious, this is now one of many fields of science in which there are very few able academic researchers who do not have links of some kind with some commercial organization, commonly undisclosed.

So has the time come to recognize that the peer-review system has broken down? Again, the answer is flatly no. The interest of patent attorneys suggests that most authors are now keenly aware that the work they seek to report may have commercial value, and that they know what steps must be taken to protect it. Even where research has no immediate application, journals such as this do their best not to send papers for review to groups known to be in competition, or willingly follow an author's request that the referees should not include people working in named laboratories. (Nervous authors would be comforted to know how often referees disqualify themselves on the grounds that they have too direct an interest.)

There is, however, unsystematic evidence, chiefly what seems to be a greater volume of complaint, that some referees are now less than strictly bound by the request that they should deal confidentially not merely with the content of the manuscripts they are sent but even with the fact that they exist. The damage done by such transgressions is intangible but no less worrying on that account. The chief casualty is the civility of academic life. Authors are entitled to expect that their papers will be dealt with privately. Not merely their self-esteem but their public reputation may easily be damaged unfairly by gossip, necessarily incomplete, about the ways in which their latest attempts at publication have been handled. Erring referees should reflect that they are usually authors as well.

John Maddox 